\title{
THE EFFECT OF MSME's FINANCIAL STATEMENTS QUALITY TO BANKING CREDIT ACCESSIBILITY
}

\author{
Rizka Rahmah Asaidah ${ }^{1}$, Khairina Nur Izzaty ${ }^{2}$ \\ ${ }^{1,2}$ Accounting Department of STIE Bank BPD Jateng \\ Email: rizkarahma2301@gmail.com,izzaty33@gmail.com
}

\begin{abstract}
The purpose of this study is examine the extent to which SMEs actors prepare annual reports and how the level of loan access that can be received by SMEs with quality annual reports. This study uses primary data obtained from question with respondents of 50 SMEs at Rumah Kreatif BUMN Bank BRI Cabang Pandanaran Semarang. The analysis technique used multiple linier regression. The results of this study indicate that the quality of SMEs annual report and loan term has no effect on the bank loans access, this is due to the low SMEs annual reports that cause banks to still doubt the trust related to their annual report. While the size of the business, length of business, and loan collaterals have a positive effect on the amount of bank loans access.
\end{abstract}

Keyword: $\quad$ Financial reports, SMEs, banking access, credit.

\section{Background}

Micro, Small and Medium Enterprises (MSMEs) have an important role in the economy of the Indonesian. The Indonesian government takes seriously the existence of SMEs. The proof is that MSMEs and Cooperatives have a special place under the Ministry of Cooperatives and MSMEs. In addition, MSME has become one of the livelihoods of economic activities in Indonesia, because with this MSME, the population without jobs is reduced. The MSME sector has been promoted and made an important activity in developing the Indonesian economy. Therefore, efforts are needed to improve MSMEs in Indonesia by optimizing economic potentials (Prajanto \& Septriana, 2018).

Quoted from detikFinance $(07 / 22 / 18)$, according to data from Bank Indonesia and the Financial Services Authority (OJK), as many as $70 \%$ of the total of nearly 60 million MSME units in Indonesia have yet to get access to financing from banks. According to data from the Ministry of Cooperatives and Micro, Small and Medium Enterprises (MSMEs), in 2018 the contribution of MSMEs to Gross Domestic Product (GDP) reached 60.34\%, and employment of 116.73 million people or $97.02 \%$ of the total labor force that works. The lack of funding for MSMEs due to administrative difficulties, as well as financial and business management which is generally still managed manually.

The government has issued a financing policy to MSMEs in the form of People's Business Credit (KUR). KUR is a working capital or investment financing design for Micro, Small and Medium Enterprises (MSMEs). MSME that is entitled to get KUR is a productive and feasible type of business, but is unable to meet the requirements set by banks (not yet bankable). The role of the People's Business Credit (KUR) in increasing MSMEs will significantly boost the national economy. MSME continues to show the development of its business. This can be seen from the attitude of MSMEs asking banks through the government to add the highest limit of KUR in 2018. Previously the highest limit of funds provided by KUR was IDR 117.08 trillion and will be added more to IDR 123.53 trillion. The addition of the highest limit provides evidence that the enthusiasm of MSMEs is increasing and developing (source: www.kur.ekon.go.id/). 
International Journal of Economics, Business and Accounting Research (IJEBAR)

Peer Reviewed - International Journal

Vol-4, Issue-3, 2020 (IJEBAR)

E-ISSN: 2614-1280 P-ISSN 2622-4771

http://jurnal.stie-aas.ac.id/index.php/IJEBAR

Accountable and fairly of accounting information makes it easier for MSME practitioners to submit KUR to banks. However, it is not easy for MSME practicioners to submit KUR in banks, because they still financial statements are not something important in their business processes. There are still other obstacles faced by MSMEs such as educational backgrounds that do not understand accounting or bookkeeping, are less routine when carrying out accounting books, and there are no more costs for hiring accountants at Rudiantoro \& Siregar (2012).

With the problem of recording transactions on MSME actors that are prepared to meet the financial reporting needs of MSME businesses, on October 24, 2016 the Indonesian Accountants Association (IAI) has issued Financial Accounting Standards for Micro, Small and Medium Enterprises (SAK EMKM). The purpose of SAK EMKM is intended to be used by micro, small and medium entities. Basically, MSMEs are entities without accountability because MSMEs do not yet have significant public accountability and do not report their finances for general purposes. Previously, in 2009 the Financial Accounting Standards Board - Indonesian Accounting Association (DSAK IAI) issued the Financial Accounting Standards for Entities Without Public Accountability (SAK ETAP), but because of the efficiency and effectiveness of use for smaller entities, the use of SAK ETAP became irrelevant. So effectively for the preparation of financial statements starting January 1, 2018 SAK EMKM applies (source: www.iaiglobal.or.id).

In order to increase the capacity and capability of MSMEs, one of the BUMN Banks, namely BRI Bank Pandanaran Semarang Branch established BUMN Creative Houses which is a place for SOE collaborative steps in forming the Digital Economy Ecosystem through fostering MSMEs to increase the capacity and capabilities of MSMEs themselves. BUMN Bank BRI Creative House, Pandanaran Semarang Branch will be played as a data and information center and as a center for education, development and digitalization of MSMEs. The main objective of BUMN Creative Homes is to increase the capacity and capability of MSMEs so that they can realize quality Indonesian MSMEs. The location used as BUMN Creative House will utilize the location of the accompanying branch office in the relevant regency or city. This place is one of the things that accompanies and encourages MSME entrepreneurs in answering the main challenges of MSME business development in terms of increasing competence, increasing marketing access and ease of access (source: www.rkb.id )

From the results of previous studies, quality financial reports will produce quality information in decision making (Sarwani, Nailiah, \& Latif, 2019). Other research conducted by Cziráky, Tišma, \& Pisarović, (2005) shows that banks experience difficulties when assessing loan worthiness without obtaining complete information from their debtors. These difficulties resulted in low levels of bank lending. The low quality of MSME financial reports resulted in the quality of the financial statements not having a positive effect on the amount of credit access. Thus, researchers will test the quality of MSME financial statements on the amount of access to banking loan.

Based on the background description above, it is interesting to do research by replicating previous research conducted by Prajanto \& Septriana, (2018) who tested the Implementation of SAK EMKM Implementation and its Impact on the Quality of MSME Financial Reporting. This study tries to replicate and develop previous research and find out the extent of the influence of the quality of MSME financial statements on access to bank loan.

\subsection{Problem Formulation}

Based on the background above, the formulation of the problems that arise in this study are:

1. To what extent do SMEs prepare quality financial reports?

2. What level of access to banking loan can be received by MSME entrepreneurs with quality financial reports? 
International Journal of Economics, Business and Accounting Research (IJEBAR)

Peer Reviewed - International Journal

Vol-4, Issue-3, 2020 (IJEBAR)

E-ISSN: 2614-1280 P-ISSN 2622-4771

http://jurnal.stie-aas.ac.id/index.php/IJEBAR

\subsection{Research Objectives}

The purpose of this study are:

1. To find out the extent to which SMEs prepare quality financial reports.

2. To find out how the level of access to banking loan can be received by MSME entrepreneurs with quality financial reports.

\subsection{Literature Review}

\subsubsection{Underlying Theories}

\section{Micro, Small and Medium Enterprises}

According to Law Number 20 Year 2008, MSMEs have the following criteria:

1. Micro Business, which is a productive business owned by an individual or a business entity owned by an individual that meets the criteria of having a maximum net worth of IDR $50,000,000$ (fifty million rupiahs excluding land and buildings where the business is located. Then having annual sales results of at most IDR 300,000,000 (three hundred million rupiah).

2. Small Business, which is a standalone productive economic business carried out by an individual or business entity that is not a subsidiary or branch company that is owned, controlled or become a part either directly or indirectly of a medium-sized business or large business that meets the criteria of has a net worth of more than IDR 50,000,000 (fifty million rupiah) up to a maximum of IDR 500,000,000 (five hundred million rupiah). Excludes land and business premises. In addition it also has annual sales results of more than IDR $300,000,000$ (three hundred million rupiah) up to a maximum (IDR 2,500,000,000 (two billion five hundred million rupiah).

3. Medium-sized Business, that is a productive economic business that stands alone, which is carried out by individuals or business entities that are not subsidiaries or branch companies that are owned, controlled, or become a direct or indirect part of small businesses or large businesses that meet the criteria in the form of having a net asset of more than IDR $500,000,000$ (five hundred million rupiah) up to a maximum of IDR 10,000,000,000 (ten billion rupiah) excluding land and buildings for business premises. And also has annual sales results of more than IDR 2,500,000,000 (two billion five hundred million rupiah) up to a maximum of IDR 50,000,000,000 (fifty billion rupiah).

According to the Central Statistics Agency (BPS): The Central Statistics Agency (BPS) defines MSMEs based on the quantity of labor. Small businesses are businesses that have a workforce of 5 to 19 people, while medium-sized businesses are businesses that have a workforce of 20 to 99 people. According to the Ministry of Finance: Based on the Decree of the Minister of Finance No. 316 / KMK 016/1994 dated June 27, 1994 that Small Businesses as individuals or business entities that have carried out activities or businesses that have annual sales or turnover of a maximum of IDR $600,000,000$ or assets (assets) as high as possible IDR $600,000,000$ (excluding land and buildings occupied).

\section{Quality of Financial Statements}

According to Rosidiani (2011), the quality of financial statements is the extent to which the financial statements prepared provide true and honest information. Quality financial reports are useful to be used as economic decision making for interested parties. Complete financial records and readiness in forming financial statements will affect the quality of financial statements. PSAK No. 1 describes the presentation of financial statements consisting of the structure of financial statements, and the requirements for the contents of financial statements. The information is public and does not apply to Islamic financial statements. This happens so that the financial statements can be arranged clearly and neatly structured, so that the Financial

Accounting Standards state the requirements and how to prepare the correct one.

The Indonesian Accounting Association (IAI) as a professional organization that houses all accountants in Indonesia always fulfills its commitment to participate in advancing the country's 
International Journal of Economics, Business and Accounting Research (IJEBAR)

Peer Reviewed - International Journal

Vol-4, Issue-3, 2020 (IJEBAR)

E-ISSN: 2614-1280 P-ISSN 2622-4771

http://jurnal.stie-aas.ac.id/index.php/IJEBAR

economy. On October 24, 2016, the DSAK Financial Accounting Standards Board (IAI) has ratified Exposure Draft of the Micro, Small and Medium Entity Financial Accounting Standards (ED SAK EMKM) becomes the Financial Accounting Standards for Micro, Small and Medium Enterprises (SAK EMKM). This provides evidence that IAI's attention to all economic actors, especially MSMEs. SAK EMKM is intentionally made simple to become a Financial Accounting Standard that is easily understood by around 57.9 million SMEs.

The issuance of SAK EMKM is expected to be one of the drivers of financial literacy for MSMEs in Indonesia so as to gain wider access to financing from banks, as well as a basis for preparing and developing accounting guidelines for MSMEs engaged in various business fields. The SAK EMKM is effective as of 1 January 2018.

\section{Credit Accessibility}

Credit comes from the Greek "credere" which means trust or in Latin "creditum" which means trust and truth, therefore the basis of credit is trust. Credit lenders believe that the credit recipients will certainly be returned according to the agreement.. According to Law no. 10 of 1998 states that credit is the provision of money or bills which can be equivalent, based on the agreement or agreement between the bank and other parties that require the borrower to repay the debt after a certain period of time with interest.

According to Baskara (2013) microcredit, namely the type of channeling of funds provided to customers who have a medium-scale business scale down and tend not to have been associated with the banking world. Alberto \& Peñaloza (2015) found that there are determinants of credit access for MSMEs. These factors are the size of the company, the company that has high profits and high capital accumulation shows its ability to regulate its capital flows because they can easily produce the resources needed to repay their loans, the age of the company also influences the determinants of credit access, the longer the company stands then the cash flow obtained looks better so it's possible to get credit. The amount of credit is the amount of the loan and the period applied to be used as additional working capital for the production unit based on an assessment of production capacity and working capital requirements (Kasmir, 2004).

The government is increasing access to funding sources, among others by providing credit loans to MSMEs through the People's Business Credit (KUR). Therefore, on November 5, 2007, the President launched the People's Business Credit (KUR), with a credit collateral facility from the Government. According to the Coordinating Ministry for Economic Affairs of the Republic of Indonesia People's Business Credit (KUR) is credit or financing of working capital and / or investment to individual / individual debtors, business entities and / or business groups that are productive and feasible but do not yet have additional collateral or additional collateral is not enough KUR distribution can be done directly, meaning that MSMEs and cooperatives can directly access KUR at the Branch Office or Sub-Branch Office of the Implementing Bank (source: www.kur.ekon.go.id/).

\subsubsection{Prior Research}

Kirschenmann \& Norden (2010) in the study of the relationship between borrower risk and loan maturity in small business lending that credit terms will negatively affect the amount of credit given by banks to MSME actors. It is likely that the longer the credit period creates additional risks for the bank.

Rudiantoro \& Siregar (2012) in a study of the quality of MSME financial statements and the prospects for the implementation of SAK ETAP that the quality of MSME financial reports has no significant effect on the amount of credit received. Likely to occur because MSME financial reports have not yet become a relevant source of information for the banking sector. Then the length of the business standing variable has a significant positive effect on the amount of credit access by MSME entrepreneurs. 
International Journal of Economics, Business and Accounting Research (IJEBAR)

Peer Reviewed - International Journal

Vol-4, Issue-3, 2020 (IJEBAR)

E-ISSN: 2614-1280 P-ISSN 2622-4771

http://jurnal.stie-aas.ac.id/index.php/IJEBAR

Rahmawati \& Puspasari (2017) in their research taken in Kuningan about the implementation of SAK ETAP and the quality of MSME financial statements related to access to bank capital suggests that, the quality of financial reports has a positive and significant effect on the amount of credit received by MSME businesses when applying for bank loans. It happens that the financial statements are used as one of the requirements in applying for credit by the banks. Financial reports prepared by SMEs are one of the conditions that must be provided during the process of applying for credit to banks.

In Prajanto \& Septriana's research (2018) which examines the implementation of SAK EMKM and its impact on the quality of MSME financial reporting at MSMEs in Semarang City, that the variable quality of financial reports has no effect on access to credit. This happens because the financial statements presented may not yet be used as a banking tool in realizing credit to MSMEs. It is most likely to see the turnover and working capital needs that MSMEs want to use. On the variable business size has a positive effect on the amount of credit that is received. The age of the business establishment has no significant effect on the amount of loans disbursed. This happens because banks do not see the age of the entity as a medium to disburse its credit. Then the amount of collateral provided has a positive effect on access to credit. Then the credit period does not affect access to credit. This means that the longer the credit period does not affect the amount of credit obtained by MSMEs.

According to research from Safii \& Suwarno (2018), the length of the current business has a positive and significant effect on credit acquisition. While the number of employees and monthly business turnover has a positive but not significant coefficient for the acquisition of credit that will be received by MSMEs. The results of the analysis that get positive coefficients indicate an increase in the value of each variable, to increase the chances of credit proposals submitted by MSME actors, but the smaller the value of these variables will hinder the chances of obtaining credit for MSME actors.

Sarwani et al., (2019) in their research, the quality of financial statements did not significantly influence the amount of credit received. This is because the quality of financial statements can not be accepted and used in decision making in granting loans from banks. According to the results of the test, business size has a positive and significant effect on the amount of credit received. This means that the greater the size of the business, the greater the resources or assets owned by MSMEs, thus enabling the MSMEs to obtain large amounts of credit. Business life does not affect the amount of credit received, this result is not in line with Rudiantoro \& Siregar (2012) which stated that there is a positive influence between the age of the business and the amount of credit received. From the results, it means that the age of the business does not become a mandatory requirement for banks to be able to extend their credit to MSMEs. Furthermore, credit collaterals have a significant positive effect on the amount of credit received. In this case, credit collaterals are important for banks to be able to provide credit loans. Then for credit terms, it has a significant negative effect on the amount of credit received. Bebczuk \& Bebczuk (2004) examined the determinants of MSME credit access in Argentina. The main result of the empirical finding was that there was no significant effect of firm size on opportunities to obtain bank credit. There was a positive relationship between company profitability and opportunities to obtain bank credit and performance past the company's debt in the bank has a significant impact. While the collateral does not seem to have an effect.

\subsection{Hypothesis Development}

Quality financial reports will produce quality information in decision making (Sarwani et al., 2019), so that the quality of financial statements has a positive effect on the credit received. Other research conducted by Cziráky et al. (2005) that banks experience difficulties when assessing credit worthiness and do not obtain complete information from their debtors. These difficulties resulted in low levels of bank lending. The low quality of MSME financial reports resulted in the quality of financial reports not having a positive effect on the amount of credit 
International Journal of Economics, Business and Accounting Research (IJEBAR)

Peer Reviewed - International Journal

Vol-4, Issue-3, 2020 (IJEBAR)

E-ISSN: 2614-1280 P-ISSN 2622-4771

http://jurnal.stie-aas.ac.id/index.php/IJEBAR

access.

H1 = Quality of financial statements has a positive effect on access to bank credit.

Mac an Bhaird \& Lucey (2010) suggested that small companies have a higher risk than large companies in terms of their ability to pay off credit. That is, the size of the company becomes one of the factors in granting credit. The greater the size of the company, the greater the likelihood of obtaining a loan. The analysis is in line with the study of Sarwani et al., (2019) that business size has a positive and significant effect on the magnitude of the magnitude credit received.

H2 = Business size has a positive effect on access to bank credit.

Furthermore, according to Sarwani et al., (2019) and Rudiantoro \& Siregar (2012) the age of the business is also a factor in determining banks on the feasibility of providing credit loans. provide credit loans compared to newly established MSMEs. Chrissentia and Syarief (2018) suggests that newly established companies have a greater risk of failure when compared to a long-established

H3 = Business duration has a positive effect on access to bank credit.

company.

According to Siswanto, Arifin, \& Cavin (2019) in their analysis of the important factors that determine credit approval for Micro, Small and Medium Enterprises that the value of collateral owned by a prospective debtor can affect the realization of loans provided by banks. When a debtor is declared bankrupt and cannot repay the debt, the debtor's collateral assets will be executed, and the value will be used to repay the debt. This explanation reinforces the research of Sarwani et al. (2019) that credit collaterals have a significant positive effect on the amount of credit

received.

H4 = The amount of collateral has a positive effect on access to bank credit received by MSMEs

Furthermore, credit terms are also considered to have an effect on the amount of credit received by MSMEs. Kirschenmann \& Norden (2010) in his research, that the greater the credit period, the greater the risk of credit repayment. With these conditions, it means that credit terms negatively affect the amount of bank credit received by MSMEs.

H5 $=$ Credit term has a negative effect on access to bank credit

\section{Research Method}

\subsection{Population and Sample}

This research was carried out using a population of MSME entrepreneurs found in the BUMN BRI Bank Creative Home, Pandanaran Semarang Branch. For sample selection using purposive sampling with the following criteria:

1. The MSME fulfills the criteria of being MSME in accordance with Law Number 20 Year 2008

2. MSMEs that meet the criteria of having a maximum net worth of $\mathrm{Rp} 10,000,000,000$ (ten billion rupiah) excluding land and buildings where they operate.

3. UMKM which has the most annual sales results of Rp. 50,000,000,000 (fifty billion rupiah).

4. Ever submitted KUR.

\subsection{Data Collection Methods}

The purpose of collecting data is to get the material needed for research. The method used is to use a questionnaire. The questionnaire is a data collection technique by distributing questionnaires in which a written list of questions is closed (Sugiyono, 2014: 199). The research questionnaire was distributed by visiting respondents and sending a Google form to the whatssapp group of the BUMN BRI Creative House Rumah Pandanaran Semarang Branch. 
International Journal of Economics, Business and Accounting Research (IJEBAR)

Peer Reviewed - International Journal

Vol-4, Issue-3, 2020 (IJEBAR)

E-ISSN: 2614-1280 P-ISSN 2622-4771

http://jurnal.stie-aas.ac.id/index.php/IJEBAR

\subsection{Operational Definitions}

The operational definition is the translation of variables arising from a study into more detailed indicators. The variables used by researchers in this study are dependent and independent variables.

\subsubsection{Independent Variable $(X)$}

Is a variable that is the cause of the emergence or change of the dependent variable. The independent variables of this study are:

X1. The Quality of MSME Financial Statements In this study, the index of the quality of financial statements is assessed based on:

1. Does the MSME perform accounting books? If you answer "Yes" then get points 1 , and 0 for the answer "No".

2. Are there sections or employees that are specialized in making financial accounting and reporting? Points 1 are given if you answer "Yes" and 0 for "No" answers.

3. Is there accounting software that supports the accounting? Points 1 are given if you answer "Yes" and 0 for "No" answers.

4. Is accounting bookkeeping and financial reporting routinely made? If you answer "Routine" get points 1 and 0 for the answer "No".

5. What accounting standards are used in preparing financial statements? If the answer "SAK EMKM", or "Taxation Rules" or "Other" gets a value of 1, and if the answer "Don't Know" is given a value of 0 .

6. Components of financial statements that will be made (there are 5 components of financial statements). Can answer more than 1 choice and each choice has 1 point, with a maximum point of 5 .

7. Points obtained from each of these questions are added up to get an index number of the quality of financial statements.

\section{X2 Business Size}

The size of the business is determined based on the number of employees, total assets, and sales value. Here are questions and answer choices to find out the size of the business:

1. Number of Employees:

a. <4 people

b. 5-19 people

c. 20-99 people

d. 100 people

2. Company Assets:

a. <from IDR 50 million

b. IDR 50 million - IDR 300 million

c. IDR 300 million - IDR 2.5 billion

d. IDR 2.5 billion - IDR 50 billion

3. Sales Company:

a. <from IDR 50 million,

b. IDR 50 million - IDR 300 million

c. IDR 300 million - IDR 2.5 billion

d. IDR 2.5 billion - IDR 50 billion

Each answer option is given a value of 1 for answer "a", 2 for answer "b", 3 for "c", and "4" for " $\mathrm{d}$ ". The value of the three questions is summed and based on the results of the sum the business sizes are grouped into micro business groups for values between 1-4, small businesses between $5-8$, and values $>9$ are classified as medium businesses.

X3 Duration of Business Establishment 
International Journal of Economics, Business and Accounting Research (IJEBAR)

Peer Reviewed - International Journal

Vol-4, Issue-3, 2020 (IJEBAR)

E-ISSN: 2614-1280 P-ISSN 2622-4771

http://jurnal.stie-aas.ac.id/index.php/IJEBAR

The length of the establishment of the business becomes one of the considerations in the assessment of a business both by banks and investors, because from the age of this business, the business stage of the business can be known along with the track record of the business undertaken so far. months to 2 years, and 3 for a long time the business stood more than 2 years.

X4 Credit Collateral

Represents the value of assets owned by MSMEs that are used as collateral for credit applications. Points awarded for answers to answers to this question are 1 if there are no collaterals, 2 for collaterals of less than IDR 10,000,000, 3 for IDR 10,000,000 - IDR 25,000,000, 4 for IDR 50,000,000 - IDR 100,000,000, and 5 for more than IDR 100,000,000.

X5 Credit Term

Represents a period of time given to MSMEs to be able to pay or repay their credit loans. The value given for the answer to this question is 1 for credit terms less than 1 year, 2 for credit terms $>1$ year to 3 years, and 3 for credit terms for more than 3 years.

Dependent Variables (Y)

The dependent variable or the dependent variable is:

Y. Access credit

In accessing credit, it is judged by looking at the large amount of credit received by MSMEs from banks. Points given for the answer to this question are 1 for less than IDR 10,000,000, 2 for IDR 10,000,000 - IDR 25,000,000, 3 for IDR 25,000,000 - IDR 50,000,000, 4 for IDR $50,000,000$ - IDR 100,000. 000, and 5 for more than IDR 100,000,000.

\subsection{Data Analysis Methods}

The data analysis method used in this study is statistical analysis with the help of the SPSS program. The form of the regression equation is formulated based on a hypothesis developed using multiple linear regression, as follows:

\section{Classical Assumption Test}

The classic assumption test is used to underlie and the requirements for statistics that must be met in the use of multiple regression analysis, namely the linear regression coefficient, unbiased, consistent, and efficient. The classic assumption test for primary data is the normality test, multicollinearity test and heteroscedasticity test

\section{Results and Discussion}

\subsection{Validity and Reliability}

In this study, the variables that can be done validity and reliability are the variable Quality of Financial Statements (X1) and Business Size Variables (X2) because they have several questions. Other variables only consist of 1 question so the validity and reliability calculations cannot be done. Validity test is used to measure the validity of a question in the questionnaire. Validity test is done by looking at the correlation between the answers of respondents on each item with the total answers of respondents from all questions. If the significance value for each of these questions is $<0.05$, it can be said that the question is valid. The results obtained are as follows:

Table 3.1

Validity Analysis

\begin{tabular}{|c|c|c|}
\hline & Significance & Decision \\
\hline \multicolumn{2}{|c|}{ SME'S Financial Statement Quality (X1) } & Valid \\
\hline Question 1 & 0,000 & Valid \\
\hline Question 2 & 0,003 & Valid \\
\hline Question 3 & 0,000 & Valid \\
\hline Question 4 & 0,000 & Valid \\
\hline Question 5 & 0,001 & Valid \\
\hline Question 6 & 0,000 &
\end{tabular}


International Journal of Economics, Business and Accounting Research (IJEBAR)

Peer Reviewed - International Journal

Vol-4, Issue-3, 2020 (IJEBAR)

E-ISSN: 2614-1280 P-ISSN 2622-4771

http://jurnal.stie-aas.ac.id/index.php/IJEBAR

\begin{tabular}{|c|c|c|}
\hline Business Size (X2) & \\
\hline Question 1 & 0,000 & Valid \\
\hline Question 2 & 0,000 & Valid \\
\hline Question 3 & 0,000 & Valid \\
\hline
\end{tabular}

The table above shows that the significance value of the six questions of the MSME Financial Report Quality (X1) variable is less than 0.05 . So it can be concluded that the answer data on questions related to the Quality of MSME Financial Report (X1) is valid. Furthermore, the three questions related to the Business Size variable (X2) obtained a significance value of less than 0.05. So we get the conclusion that the answer data on questions related to Business Size (X2) is valid.

The next analysis is the reliability test conducted to find out the stability and consistency of the respondent in answering matters relating to the question items which are the dimensions of a variable. The reliability test results on the variable Quality of Financial Statements (X1) and Business Size variables (X2) are as follows:

Table 3.2

Reliability Test

\begin{tabular}{|l|c|c|}
\hline \multicolumn{1}{|c|}{ Variable } & Alpha Score & Decision \\
\hline Financial Statement Quality (X1) & 0,580 & Quite Reliable \\
\hline Business Size (X2) & 0,562 & Quite Reliabel \\
\hline
\end{tabular}

The table above shows that the Financial Quality (X1) variable obtained alpha value on the reliability test of 0.580 which means included in the category of "Quite Reliability". On the Business Size variable (X2) obtained an alpha value of 0.562 which is also included in the category of "Quite Reliable ".

\subsection{Descriptive Statistics}

In this research, descriptive statistical analysis is performed using crosstab tables. This table is used to show the grouping between variables $\mathrm{X}$ with $\mathrm{Y}$ in the form of rows and columns. The results of the crosstabs table on the first question value of financial statement quality variable (X1) with the value of credit access variables (Y) is as follows:

1. As many as 24 respondents who did accounting books, received credit access of <IDR $10,000,000$.

2. A total of 34 respondents had a special employee to do bookkeeping, then they would receive credit access of $<$ IDR 10,000,000

3 . There were 30 respondents who did not use accounting software, received credit access in the amount of <IDR 10,000,000

4. As many as 21 respondents did not routinely do financial bookkeeping and reporting, then received access to credit $<$ IDR $10,000,000$

5. 19 respondents used accounting standards, and received credit access of $<$ IDR 10,000,000.

6 . there were 24 respondents who knew one component of the financial statements prepared, and received a credit of <IDR 10,000,000

The results of the crosstabs table analysis in the first question business size variable (X2) with the credit access variable $(\mathrm{Y})$ are as follows:

1. there were 34 respondents who had $<4$ employees, then received credit access of <IDR $10,000,000$

2. 32 respondents had company assets of <IDR. 50,000,000, and then received a total access to credit of <IDR. 10,000,000.

3. 32 respondents whose company sales were $<$ IDR 50,000,000 received credit access in the amount of < IDR 10,000,000. 
International Journal of Economics, Business and Accounting Research (IJEBAR)

Peer Reviewed - International Journal

Vol-4, Issue-3, 2020 (IJEBAR)

E-ISSN: 2614-1280 P-ISSN 2622-4771

http://jurnal.stie-aas.ac.id/index.php/IJEBAR

Furthermore, the results of the analysis of the crosstabs table on the Variable Length of Business (X3) with the value of the variable credit access (Y) are there were 27 respondents whose business duration was $<6$ months, receiving a total credit of $<$ IDR $10,000,000$.

Then the results of the analysis of the crosstabs table on the credit collateral variable (X4) with the credit access variable $(\mathrm{Y})$ is that there are 27 respondents with no credit collateral, receiving credit access of $<$ IDR $10,000,000$

The results of the analysis of the crosstabs table on the loan term variable (X5) with the value of the credit access variable $(\mathrm{Y})$ is that a number of 15 respondents chose credit terms $>3$ years, get credit access of $<$ IDR 10,000,000.

\subsection{Classical Assumptions}

In this research classical assumption analysis will be carried out to find out that the research data used is appropriate for multiple regression analysis. The classical assumptions used in this study use the assumption of normality, heteroscedasticity assumptions, and multicollinearity assumptions. The results of the classical assumption analysis are as follows:

Table 3.3

Classical Assumptions Test

\begin{tabular}{|l|l|l|r|l|l|l|}
\hline $\begin{array}{l}\text { Normality } \\
\text { Test }\end{array}$ & Score & $\begin{array}{l}\text { Heteroscedasticity } \\
\text { Test }\end{array}$ & Score & $\begin{array}{l}\text { Multicollinearity } \\
\text { Test }\end{array}$ & Tolerance & VIF \\
\hline Asymp. Sig & 0,067 & X1 & 0,341 & X1 & 0,872 & 1,147 \\
\hline & & X2 & 0,426 & X2 & 0,600 & 1,667 \\
\hline & & X3 & 0,220 & X3 & 0,676 & 1,480 \\
\hline & & X4 & 0,409 & X4 & 0,733 & 1,364 \\
\hline & X5 & 0,300 & X5 & 0,753 & 1,327 \\
\hline
\end{tabular}

Analysis of the normal distribution assumptions in the above table shows that the significance value is 0.067 which means it is greater than the value of 0.05 so that the conclusion is that the transformation data meets the normality assumption. Then the data used for subsequent analyzes is the result of transformation.

The results of the heteroscedasticity assumption test analysis above show that the significance value of the MSME financial report quality variable (X1) is 0.341 , then the business size variable (X2) obtained a significance value of 0.426 , the business length variable (X3) obtained a significance value of 0.220 Then in the credit collateral variable (X4) there is a significance value of 0.409 , and in the credit term variable (X5) a significance value of 0.300 is obtained. The significance values are $>0.05$ so that it can be concluded that there are no cases of heterokedasticity in the data or it can be said that the assumptions are met.

The results of the analysis shown in the table above show that the tolerance values of all variables are above 0.10 and all VIF values are below the value of 10 . It shows that the data in this study do not have multicollinearity or it can be said that the assumptions have been fulfilled.

\subsection{Analysis of Multiple Linear Regression 3.4.1 Regression Model}

Regression equation model of this research is as follows:

$Y=0,283+0,0002 X_{1}+0,835 X_{2}+0,238 X_{3}+0,046 X_{4}+0,021 X_{5}$

Based on the equation of the regression model it can be seen that for every one point increase in the quality of MSME financial statements (X1), access to credit (Y) will increase by 0,0002 points. For every one point increase in business size (X2), access to credit (Y) will increase by 0.835 points. For every increase of one point in business (X3), access to credit (Y) will increase by 0.238 points. For every one point increase in credit collateral $(\mathrm{X} 4)$, credit access $(\mathrm{Y})$ will 
International Journal of Economics, Business and Accounting Research (IJEBAR)

Peer Reviewed - International Journal

Vol-4, Issue-3, 2020 (IJEBAR)

E-ISSN: 2614-1280 P-ISSN 2622-4771

http://jurnal.stie-aas.ac.id/index.php/IJEBAR

increase by 0.046 points. For every one point increase in credit terms (X5), credit access (Y) will decrease by 0.021 points.

\subsubsection{Coefficient of Determination Test}

The coefficient of determination in this study are as follows:

Table 3.4

T Test Analysis

\begin{tabular}{|c|c|}
\hline Model & Adjusted R Square \\
\hline 1 & 0,556 \\
\hline
\end{tabular}

Based on table 3.4 it can be seen that the MSME financial report variability (X1), business size (X2), length of business (X3), credit collaterals (X4), and credit terms (X5) can explain the variability in the sacrificial credit variable $(\mathrm{Y})$ of $55.6 \%$. In addition, the remaining $44.4 \%$ is explained by other variables not included in the model or research.

\subsubsection{F Test}

Testing the significance test simultaneously between MSME financial statements, business size, length of business, credit collaterals, and credit terms to access credit using Analysis of Variance is used to determine whether the model is significant or not.

Based on the table above, it can be seen that the significance value in the $\mathrm{F}$ test for multiple linear regression is 0,000 less than 0.05 . So it can be concluded that the MSME financial statement variables (X1), business size (X2), length of business (X3), credit collaterals (X4), and credit terms (X5) simultaneously have a significant effect simultaneously on access to credit loans (Y).

\subsection{4 t Test}

Partial test analysis ( $t$ test) in multiple linear regression was performed to determine the effect of each independent variable (Variable X) on the dependent variable (Variable Y). The results of the partial test analysis are as follows:

t Test Analysis
\begin{tabular}{|c|c|c|}
\hline Model & t & Sig. \\
\hline (Constant) & $-2,010$ & 0,051 \\
\hline SME's Financial Statement Quality $\left(\mathrm{X}_{1}\right)$ & 0,107 & 0,915 \\
\hline Business Size $\left(\mathrm{X}_{2}\right)$ & 3,100 & 0,003 \\
\hline Length of Business $\left(\mathrm{X}_{3}\right)$ & 3,163 & 0,003 \\
\hline Credit Collateral $\left(\mathrm{X}_{4}\right)$ & 2,666 & 0,011 \\
\hline Credit Term $\left(\mathrm{X}_{5}\right)$ & $-1,150$ & 0,257 \\
\hline
\end{tabular}

Based on the above table, it is known that the MSME financial report quality variable (X1) obtained a significance value of 0.915 , which means more than 0.05 and $t$ value of 0.107 . So it can be concluded that the quality of MSME financial statements (X1) does not affect the variable access to credit (Y).

In the variable business size (X2) obtained a significance value of 0.003 which means less than 0.05 and $t$ value of 3.100. So it can be concluded that the business size variable (X2) has a positive effect on the variable access to bank credit (Y).

In the length of business variable (X3) get a significance value of 0.003 which means less than 0.05 and $t$ value of 3.163. So we get the conclusion that the variable length of business (X3) has a positive effect on the variable access to bank credit (Y). 
International Journal of Economics, Business and Accounting Research (IJEBAR)

Peer Reviewed - International Journal

Vol-4, Issue-3, 2020 (IJEBAR)

E-ISSN: 2614-1280 P-ISSN 2622-4771

http://jurnal.stie-aas.ac.id/index.php/IJEBAR

In the credit collateral variable (X4), a significance value of 0.011 is obtained, meaning less than 0.05 and a t value of 2.666. So it can be concluded that the variable credit collateral (X4) has a positive effect on the variable access credit credit (Y).

In the credit term variable (X5) get a significance value of 0.257 , which means more than 0.05 and $t$ value of -1.150 . So it can be concluded that the credit term variable (X5) does not affect the variable access to credit (Y).

\subsection{Discussion}

\subsubsection{Effect of MSME financial statements (X1) on access to credit (Y)}

Testing the hypothesis in multiple linear regression shows that MSME financial statements do not affect credit access. Significant results obtained from the significance value in the statistical test table $\mathrm{t}$ greater than 0.05 that is equal to 0.915 (H1 rejected). This situation makes MSME actors not yet mastered about making quality financial reporting. The low quality of financial statements owned by MSMEs makes obstacles for the banks because they cannot be used as information in making decisions to get credit from banks.

In accordance with the opinion of Pranto \& Septriana (2018) which states that the variable quality of financial statements has no effect on access to bank credit. This happens because the financial statements presented may not yet be used as a banking tool in realizing credit to MSMEs.

\subsubsection{Effect of business size (X2) on access to credit (Y)}

Hypothesis test results on multiple linear regression indicate that business size has a positive influence on credit access. From the significant results obtained from the significance value in the statistical test table $t$ less than 0.05 i.e. 0.003 (H2 received). This results in the size of the business has a positive influence on access to credit, meaning that if the company has a small business size, the risk of paying off credit is large. Unlike companies that already have large business sizes, the MSME can obtain large amounts of credit, because it has a lot of resources and assets.

The results of this study are in accordance with the opinion of Prajanto \& Septriana (2018) which states that the business scale variable has a positive effect on the amount of credit received. In addition, the results of this study are also in accordance with the opinion of Sarwani et al. (2019) which states that business size has a positive and significant effect on the amount of credit received. This means that the greater the size of the business, the greater the resources or assets owned by MSMEs, so that it allows MSMEs to obtain large amounts of credit.

The opinion of Bhaird \& Lucey (2010) which suggests that small companies have a higher risk than large companies in terms of their ability to pay off credit. That is, the size of the company is one factor in granting credit. The larger the size of the company, the greater the possibility of getting a loan.

\subsubsection{Effect of business length (X3) on access to credit (Y)}

Hypothesis testing in multiple linear regression shows that the business effort has a positive effect on access to credit. Significant results were obtained from the significance value in the $t$ test table which was less than the 0.05 significance level that was 0.003 (H3 accepted). This means that the length of business makes the conditions for getting access to credit received from banks. If the business runs less than 6 months, the bank is not willing to provide credit loans.

The results of this study are not in line with Prajanto \& Septriana (2018) which states that the age of business standing does not significantly influence the amount of loans disbursed. This happens because banks do not see the age of an entity as a medium to disburse its credit. The same results were also stated by Sarwani et al. (2019) which states that the age of the business does not affect the amount of credit received. 
International Journal of Economics, Business and Accounting Research (IJEBAR)

Peer Reviewed - International Journal

Vol-4, Issue-3, 2020 (IJEBAR)

E-ISSN: 2614-1280 P-ISSN 2622-4771

http://jurnal.stie-aas.ac.id/index.php/IJEBAR

But the results of the study in line with Rudiantoro \& Siregar (2012) which states that there is a positive influence between the age of the business and the amount of credit received. From these results it means that banks will be willing to provide large credit loans to MSMEs whose businesses have been established for a long time.

\subsubsection{Effects of credit collaterals (X4) on access to credit $(Y)$}

The partial hypothesis test results in multiple linear regression indicate that credit collaterals have a positive effect on credit access. Significant results were obtained from the significance value in the $\mathrm{t}$ test table which was less than the 0.05 significance level that is equal to 0.011 (H4 accepted). Credit collaterals make it important for banks, because access to credit is in accordance with the assets of MSMEs. This means that if there are no collaterals for MSMEs as a banking requirement, then access to credit cannot be substantial.

The results of this study are consistent with research conducted by Sarwani et al. (2019) and Siswanto, Arifin, \& Cavin (2019) which stated that there was a positive and significant effect between credit collaterals and the amount of credit received. However, the results of this study were not in line with research conducted by Bebczuk (2004) which stated that collaterals credit standing has no significant effect on the amount of loans disbursed.

3.5.5 Effects of credit terms (X5) on access to credit (Y)

Based on partial hypothesis testing in multiple linear regression shows that credit terms do not affect credit access. Significant results are obtained from the significance value in the t test table which is more than 0.05 significance, that is 0.257 (H5 is rejected). From the test results, it means that whatever time period is taken as a credit term as determined by the bank, then credit access banking will not be affected.

The results of this study are in line with the analysis conducted by Prajanto \& Septriana (2018) that the longer credit period does not affect the amount of credit received by MSMEs.

\section{Conclusion}

According to the results of research on the effect of the quality of MSME financial statements on access to bank credit in the Creative House of BUMN BRI bank Semarang Pandanaran branch, the conclusions can be drawn, namely:

1. MSME financial statements have no influence on access to credit.

2. Business size has a positive effect on access to bank credit.

3. Business duration has a positive effect on access to bank credit.

4. Credit collaterals have a positive effect on access to bank credit.

5. Credit term has no influence on bank credit access.

Based on research that has been done before, for further research it is recommended that:

1. The time to distribute the questionnaire is to take longer to get more respondents.

2. Choosing clearer population data from the bank in order to find out who has already received people's business credit.

3. With this research, it is expected that MSMEs at the BUMN Creative House Bank BRI branch of Pandanaran Semarang can improve the quality and consistency of financial reporting, so as to facilitate access to credit applications.

\section{Reference}

Alberto, H., \& Peñaloza, B. (2015). Determinants of access to credit for SMEs : Evidência da empresa na América Latina. 34, 247-276.

Baskara, I. G. K. (2013). Lembaga keuangan mikro di indonesia. 18(2), 114-125.

Bebczuk, R. N. (2004). What Determines the Access to Credit by SMEs in Argentina? Documentos de Trabajo, 48, 16. Retrieved from www.depeco.econo.unlp.edu.ar

Bebczuk, R. N., \& Bebczuk, R. N. (2004). What Determines the Access to Credit by SMEs in Argentina? What Determines the Access to Credit by SMEs in Argentina? 
International Journal of Economics, Business and Accounting Research (IJEBAR)

Peer Reviewed - International Journal

Vol-4, Issue-3, 2020 (IJEBAR)

E-ISSN: 2614-1280 P-ISSN 2622-4771

http://jurnal.stie-aas.ac.id/index.php/IJEBAR

Badan Pusat Statistik (BPS) definisi UMKM.

Chrissentia, Tirza \& J. Syarief. (2018). Analisis Pengaruh Rasio Profitabilitas, Leverage, Likuiditas, Firm Age, dan Kepemilikan Institusional terhadap Financial Distress. Jurnal Sistem Informasi, Manajemen, dan Akuntansi 16(1), 45-61

Cziráky, D., Tišma, S., \& Pisarović, A. (2005). Determinants of the low SME loan approval rate in Croatia. Small Business Economics, 25(4), 347-372. https://doi.org/10.1007/s11187004-6481-0

Ikatan Akuntan Indonesia (IAI). 2016. Micro, Small, and Medium Entity Financial Accounting Standard (www.iaiglobal.or.id).

Kasmir. (2004). Bank dan Lembaga Keuangan Lainnya. Edisi Revisi, Cetakan keempatbelas, PT. Raja Grafindo Persada, Jakarta

Kementrian Keuangan Nomor 316/KMK 016/1994 tentang UMKM.

Kirschenmann, K., \& Norden, L. (2012). The Relationship between Borrower Risk and Loan Maturity in Small Business Lending. Journal of Business Finance and Accounting, 39(56), 730-757. https://doi.org/10.1111/j.1468-5957.2012.02285.x

Mac an Bhaird, C., \& Lucey, B. (2010). Determinants of Capital Structure in Irish SMEs. Small Business Economics, 35(3), 357-375. https://doi.org/10.1007/s11187-008-9162-6

Prajanto, A., \& Septriana, I. (2018a). Implementasi Penerapan SAK EMKM serta Dampaknya pada Kualitas Pelaporan Keuangan UMKM (Studi Kasus Pada UMKM Se Kota Semarang). Issn 1693-928X, 20(2), 79-89.

Rahmawati, T., \& Puspasari, O. R. (2017). Implementasi Sak Etap Dan Kualitas Laporan Keuangan Umkm Terkait Akses Modal Perbankan. Jurnal Kajian Akuntansi, 1(1), 49-62. https://doi.org/10.33603/jka.v1i1.510

Republic of Indonesia Law Number 20 Year 2008 concerning Micro, Small, and Medium Enterprises

Republic of Indonesia Law Number 20 Year 2008 concerning Banking

Rosidiani, H. T. (2011). Pengaruh sistem pengendalian internal, audit laporan keuangan, dan penerapan Good Corporate Governance Terhadap Kualitas Laporan Keuangan. Skripsi Universitas Islam Negeri Syarif Hidayatullah Jakarta.

Rudiantoro, R., \& Siregar, S. V. (2012). Kualitas Laporan Keuangan Umkm Serta Prospek Implementasi Sak Etap. Jurnal Akuntansi Dan Keuangan Indonesia, 9(1), 1-21. https://doi.org/10.21002/jaki.2012.01

Safii, abdul aziz, \& Suwarno, T. (2018). FAKTOR-FAKTOR YANG MEMPENGARUHI PEROLEHAN KREDIT OLEH PENGUSAHA MIKRO Abdul Azis Safii* dan Tri Suwarno. (22), 330-341.

Sarwani, Nailiah, R., \& Latif, dwianto mukhtar. (2019). Pengaruh Kualitas Laporan Keuangan Terhadap Umkm Serta Prospek Implementasi Sak Etap. Jurnal Ecobisma, vol.6 no 2(1), $11-29$.

Siswanto, H. P., Arifin, A. Z., \& Cavin, C. (2019). Critical Factors That Determine Credit Approval to Micro, Small, and Medium Enterprises (MSME) IN BEKASI. Etikonomi, 18(1), 93-104. https://doi.org/10.15408/etk.v18i1.6722

https://finance.detik.com/berita-ekonomi-bisnis/d-4636059/akses-modal-dan-bahan-baku-

masih-jadi-tantangan-umkm-ri

https://kur.ekon.go.id/

www.rkb.id 